\title{
An Analysis of the Implementation of PSAK 69 at PT Perkebunan Nusantara V (Persero)*
}

\author{
Yefni $^{1 *}$, Hamdani Arifulsyah ${ }^{2}$, Suci Nurulita $^{3}$ \\ ${ }^{1,2,3}$ Politeknik Caltex Riau, 28265, Pekanbaru, Indonesia
}

\begin{abstract}
Objective - This study aims to identify the impact of the application of the PSAK 69 in plantation companies in Riau, particularly in PT Perkebunan Nusantara V (Persero), and the impact of PSAK 69 to the profit gained by PT Perkebunan Nusantara V (Persero).

Methodology/ Technique - This research is a qualitative descriptive research. The approach used in this research is a case study. The object of this research is PT Perkebunan Nusantara V (Persero). PT Perkebunan Nusantara V (Persero) is a company engaged in the field of palm oil plantations. This study uses the data from PT Perkebunan Nusantara V (Persero)'s annual report in 2016 and the data is collected using interviews and documentation techniques.

Findings - The results of this study indicate that PT Perkebunan Nusantara V (Persero) has not implemented the PSAK 69 in its agricultural business. In addition, there are differences in the measurement and recording of the biological assets applied by PT Perkebunan Nusantara V (Persero) under the PSAK 69 (IAS 41). PT Perkebunan Nusantara V (Persero) measures and records its biological assets based on historical cost, so there is no gain or loss in the current period. In addition, the profit gained by PTPN V for the year ending on 31 December 2016 is too low.

Novelty - The results of this study are expected to be used as a reference for other plantation companies in implementing the PSAK 69. In addition, the results of this study are also useful to regulating agencies in developing rules and policies in the field of accounting, including in re-evaluating the PSAK 69.

Type of Paper: Review

JEL Classification: G32, M41.
\end{abstract}

Keywords: PSAK 69; Agricultural Products; Biological Assets; Profit.

\section{Introduction}

The International Financial Reporting Standard (IFRS) is an international accounting standard used as a

\footnotetext{
* Paper info: Revised: December 3, 2017

Accepted: March 7, 2018

Corresponding author: E-mail: yefni@pcr.ac.id

Affiliation: Accounting, Politeknik Caltex Riau, Indonesia
} 
reference for companies in serving high quality and transparent information for financial information users. Every company listed at a Stock Exchange is required to adhere to the standard (International Accounting Standards Board (IASB), n.d.). The standard is principle-based, so it is in need of increased judgement. 2016 marked 5 years of the IFRS in Indonesia. The adoption of the IFRS was carried out by the Financial Accounting Standards Board of Indonesia, however some standards have not yet been adopted; one of them is the International Accounting Standard (IAS) 41 on Agriculture.

The agriculture field, particularly palm oil tree plantations, has been rapidly growing in recent years. This is caused by, among other things, the generally positive business prospects of palm oil trees. Further, government regulations that encourage the development of plant-based fuels as an alternative to fossil fuel also aid the growth of the industry. Moreover, population growth around the world indirectly increases the needs for palm oil and this in turn facilitates the development of the palm oil industry. Indonesia's climate supports the fast development of palm oil tree plantations, which can be very profitable in several ways such as increased levels of employment and the industries overall contribution to Indonesia's growth domestic product. The increasing number of palm oil tree plantations in Indonesia therefore directly effects the number of investors in Indonesia.

One of the pieces of information that can be used by investors in making decisions to invest in Indonesia is financial statements. According to the PSAK 1 year 2017, financial statements provide information about a company's financial position, performance, and cash flow, which can be useful in making economical investment decisions. In order for financial statements to achieve their purpose, the information in them needs to be relevant and reliable. Palm oil tree plantations have very unique characteristics. The uniqueness lies particularly in the fast growth of the plants (biological transformation) that improves the assets value. The process of that biological transformation involves planting, degenerating, producing, and procreating to achieve qualitative and quantitative changes to the assets.

The treatment of the biological assets is very important; if a mistake is made when treating and allocating the cost for the assets, this may lead to errors in identifying and serving the information regarding their value in financial statements. As a result of this error, the financial statement becomes unreliable and will potentially mislead its users. In addition, if the asset is interpreted based on the purchase or procurement price, the information interpreted is no longer relevant to the users of the financial statement. The presentation of the financial statements must be in accordance with the regulated standards to assist stakeholders in making investment decisions. Hence, the information contained in the financial statements must be accurate, based on the real financial condition of the company, and relevant for all decision-making endeavors.

On this point, on 31 December 2015, the Indonesia's Financial Accounting Standards Board legalized the PSAK 69 on Agriculture, taking effect from 1 January 2018. However, early application of the regulation in related business fields has been allowed. The PSAK states that the value or score used in the first recognition and measurement of the biological assets is a fair value less the cost at the point of sale. Before this was implemented, the Indonesian financial accounting standards board legalized the PSAK 32, which uses gained cost as a basis to measure a biological asset. A biological asset is not specifically described in the PSAK, but is categorized as a fixed asset which is a part of the PSAK 16. So, all this time, agricultural companies have been using the PSAK 14 on Inventory and the PSAK 16 on Fixed Asset as the basis to record and measure the company's fixed assets. In the meantime, the nature of a biological asset cannot be likened to that of a fixed asset. One reason for this is the rate of depreciation applied to a biological asset, while the asset experiences growth. This is different from a fixed asset that depreciates due to a decrease in value. Due to this, it is incorrect to categorize a biological asset as a fixed asset. Alternatively, the PSAK is used by agricultural companies in Indonesia as a reference for recognizing, measuring, and revealing accounting in the related field. 
According to the PSAK 69, a cultural product is a product harvested from a biological asset owned by a business entity. A biological asset is typically live stock or a plant. Agricultural activities involve farming, forestry, annual or perennial plants, plantations, planting, flower horticulture, and fishing. The PSAK 69 also states that there is a general characteristic of an agricultural activity that covers the ability to change, the management of change, and change measurement (measurable change). Change is in the quality (genetic quality or advancement, maturity, protein level) or quantity (heredity, weight, number of buds or sprouts) which results from the biological transformation, or harvesting, measured and monitored on a regular or routine basis.

One flaw of the PSAK 32 is that the asset value included in the information interpreted for users does not reveal the real value, because the assets experience development and growth which is not reflected in the financial statement. The information interpreted in the financial statement is also irrelevant to the users of the financial information. On the other hand, the use of the fair value as the measurement of a biological asset will directly affect the company's profit.

Burnside (2005) has conducted a research on the IAS 41. The samples used in the research are Holmen, SCA, Svea Skog, and PWC Ohrlings. The research result shows that the forestry industry values forests using the method of net cash flow which has been discounted. If the information on market value is not available, the companies measure their assets using the net cash flow which has been discounted. Of all 4 companies that were interviewed, 3 state that the fair value is more reliable, however the auditor that was interviewed stated that the acquisition cost model is more reliable. In addition, the research results shows that all of the companies chose to apply the IAS 41 to the minimum extent that the standard is required to be applied.

The next research is conducted by Mates, Grosu, and Hlaciuc (2015) which focused on the difference in the implementation of the IAS 41 in terms of the recognition of the biological asset and agricultural products, and the implementation of the accounting standards in agricultural or plantation companies in Rumania. In addition, the research also analyzes the influence of the companies' financial position statement and their income statement. The research results show that there is a significant difference between the implementation of the IAS 41 and the standard that has been used by the forestry or agricultural companies in Rumania. The study also found that it is difficult to apply the IAS 41 in plantation companies in Rumania.

IAS 41 is an accounting standard provided for entities that grow and develop biological assets to gain a profit. This standard sets all recognition and measurement of the growth and development of any biological assets that gains value without being connected to any harvesting or sales activities. IAS 41 defines agricultural activities as "management by an enterprise of the biological transformation of biological assets for sale, into agricultural produce, or into additional biological assets" (IASC, 2001). Biological transformation involves the processes of planting, degenerating, producing, and procreating that causes either qualitative or quantitative change to biological assets which can be interpreted and measured. Every physical change has a direct connection to future economic benefit or value. A change in fair value of a biological asset due to harvest is also classified as a physical change.

Research on the implementation of the PSAK 69 in agriculture is a very fascinating, as the PSAK has only recently been approved by the Indonesian Financial Accounting Standards Board. Further, research regarding the implementation of the PSAK 69 has not yet been conducted in Indonesia. There has been previous research conducted by Anggraeningtyas (2013) in PT Perkebunan Nusantara XI (Persero) Kebun Getas however this is focused on the implementation of the International Accounting Standard (IAS) 41 which has not been adopted by Indonesia. The results of that research shows that PT Perkebunan Nusantara XI (Persero) Kebun Getas acknowledges each of its biological assets as a fixed asset and its agricultural product as procurement, and also measurement of any biological asset and supply is based on the historical cost.

One of the objectives of this research is to identify how the implementation of the PSAK 69 at PT Perkebunan Nusantara V (PTPN V) impacts its profit and loss. It is hoped that this research will be a reference for all agricultural plantation companies on how to implement the PSAK 69. In addition, the results 
of this research may also be beneficial to regulators in making regulations and policies and evaluating the rules and policies for plantation companies.

\section{Literature Review}

\subsection{Agricultural Activities}

IAS 41 is an accounting standard provided for entities that grow and develop biological assets to gain a profit. This standard sets all recognition and measurement of the growth and development of any biological assets that gains value without being connected to any harvesting or sales activities. IAS 41 defines agricultural activities as "management by an enterprise of the biological transformation of biological assets for sale, into agricultural produce, or into additional biological assets" (IASC, 2001). Biological transformation involves the processes of planting, degenerating, producing, and procreating that causes either qualitative or quantitative change to biological assets which can be interpreted and measured. Every physical change has a direct connection to future economic benefit or value. A change in fair value of a biological asset due to harvest is also classified as a physical change.

According to the PSAK 69, a cultural product is a product harvested from a biological asset owned by a business entity. A biological asset is typically live stock or a plant. Agricultural activities involve farming, forestry, annual or perennial plants, plantations, planting, flower horticulture, and fishing. The PSAK 69 also states that there is a general characteristic of an agricultural activity that covers the ability to change, the management of change, and change measurement (measurable change). Change is in the quality (genetic quality or advancement, maturity, protein level) or quantity (heredity, weight, number of buds or sprouts) which results from the biological transformation, or harvesting, measured and monitored on a regular or routine basis.

\subsection{Stakeholder Theory}

The stakeholder theory is closely related to this research. The stakeholder theory was introduced by Robert E. Freeman in 1984. According to Freeman, the stakeholders theory states that the manager in an organization is inclined to consider the stakeholders in his efforts to manage his organization effectively (Donaldson and Preston, 1995). To maintain the sustainability of the business, the company must not only maximize the prosperity of the shareholders, but also the prosperity of the stakeholder's interest (Jensen, 2001).

\section{Methodology}

The object of this research is PTPN V, which is located at No 43 on Rambutan Street in Pekanbaru, Riau, and has been operating since 11 March 1996. PTPN V is a company in the agricultural business and agro industry of palm oil trees and rubber trees. This research uses a qualitative descriptive method with a case study approach. The data used in this research is primary and secondary data. The primary data is acquired by performing interviews, while the secondary data is obtained by performing documentation, specifically by analyzing the annual report of PTPN V in 2016 to identify the impact of the implementation of the PSAK on the profits and losses of the company. 


\subsection{Biological Asset Treatment at PTPN V}

\subsubsection{Treatment of Biological Assets or Plantation Plants at PTPN V}

The biological assets owned by PTPN V are plantation plants that consist of rubber trees and palm oil trees. The palm oil trees are the focus of this study. PTPN V produces, as its main processed products, crude palm oil (CPO), crude palm kernel oil (CPKO), and palm kernel meal (PKM) for palm oil trees. Meanwhile the primary processed product of PTPN V for rubber trees is SIR 10 and SIR 20. In the financial statements of PTPN V, the recognition of biological assets in terms of plantation plants is classified into non-current assets and interpreted before fixed assets. In the financial statements, plantation plants are classified into two categories: immature plants and mature plants. For immature plants, all cost resulting from plantation development, labor wage, and interest fees related to credit used to develop the plantation is capitalized until commercial production is achieved.

Meanwhile maintenance costs, fertilizers, and depreciation of the palm oil trees are classified as costs of the goods sold in the current period. In addition, the biological assets of immature plants are measured based on their historical cost. The acquisition cost of the immature plants consists of direct cost such as fees for maintaining a nursery, land preparation, planting, fertilizers, and maintenance, including labor cost involved the aforementioned activities. This also includes indirect costs including general cost allocation and administration, as well as loan fees used to produce plants while the plants or trees are immature.

In mature plants, the procurement costs of immature plants are reclassified to the account for the immature plants, as the plants have started to produce palm fruits. The time period for plants or trees to be declared mature is determined by their vegetative growth, and is also based on the assessment of management, which requires that the trees are a minimum of 36 months old (3 years) or at least $60 \%$ of the whole trees has grown fruit bunches that weigh over 3 kilograms. Depreciation in trees is calculated by using the straight-line method. Management estimates that the economical value period of plantation plants or trees of 25 years as this is the expected age according to the industry in which the business entity conducts itself. In addition, the amortization of the mature trees is incorporated into the cost of the goods sold.

\subsubsection{Measurement of Biological Assets}

At PTPN V, all biological assets are measured in terms of the cost of the assets sold. The price component gained covers the costs of plantation development, labor, and interest fees for the credits used to develop the plantations. Meanwhile, biological assets such as immature trees are measured based on the cost of the assets sold covering direct costs such as maintenance of the nursery, land preparation, planting, fertilizers, and maintenance, including labor costs related to those activities. This also includes indirect costs including general cost allocation and administration, as well as loan fees used to produce plants while the plants or trees are immature.

\subsubsection{Disclosure}

PTPN V has disclosed their types and numbers, depreciation methods, age benefits, and depreciation tariff of the biological assets in their annual financial statement.

\subsubsection{Interpretation of Biological Assets as Plantation Trees in Financial Report of PTPN V}

Interpretation of the financial statement of PTPN V is arranged based on the Financial Accounting Standards in Indonesia, which covers statements and interpretations issued by the Indonesian Financial Accounting Standard Board. The process of issuing the financial statement also complies with the Pedoman Akuntansi BUMN Perkebunan in Indonesia. 
In PTPN V's financial report, its biological assets are interpreted in the Statement of Financial Position in incorrect assets group as in mature and immature trees, separated from fixed assets. Mature trees are interpreted with respect to their acquisition value after being reduced according to their depreciation as well as immature trees. Meanwhile, agricultural products are recognized as stock and are included as current assets as well as agricultural products which are ready for sale. For the maintenance of the nursery, costs relating to the purchase of seeds, and administrative maintenance are stated as the procurement costs of the seedlings. Cost accumulation will be moved to the "Immature Trees" account when the seedlings are ready to be grown in the field. Hence, nursery costs are included in the acquisition costs of mature trees.

\subsection{Treatment of Biological Assets Based on the PSAK 69 (IAS 41)}

\subsubsection{Recognition of Biological Assets}

According to the PSAK 69 on Agriculture, in the early recognition of the end period of reporting, biological assets or agricultural products are measured or valued as a fair value reduced by the cost at the point of sale. Changes in the value is recognized as profits or loss in the income statements for the current period.

The company recognizes its biological assets or agricultural products if and only if:

(a) The company controls the biological assets as a result of a past events;

(b) It provides future economical benefits in relation to biological assets benefits flowing to the company; and

(c) The fair value or acquisition costs of the biological assets can be skillfully measured.

\subsubsection{Measurement of Biological Assets}

Biological assets are measured during the initial recognition and at the end of reporting period according to fair value minus the cost at the point of sale, except where fair value cannot be skillfully measured.

\subsubsection{Interpretation of biological assets in financial statement}

Biological assets are interpreted in the statement of financial position as the fair value minus the cost at the point of sale in which they are classified as immature biological assets and mature biological assets. In addition, there needs to be an adjustment in every period to create profits or losses which have not been included as part of the net profits. The results gained from the mature biological assets will be included as stock, and the value is the fair value minus the cost at the point of sale.

\subsubsection{Disclosure}

An entity discloses its profits and losses for the current period during the early recognition of the biological assets and agriculture products, according to the change in the fair value minus the cost at the point of sale. If the information is not disclosed in the financial statement, then the entity describes the characteristics of the activities involving each group of the biological assets and size or estimate of nonfinancial from specific quantities of each group of the biological assets owned by the entity at the end of the period, and releases the agricultural products during the period.

\subsection{The Impact of the PSAK 69 on PTPN V's Profits}

Since the PSAK 69 has not been implemented at PTPN V, there is a difference in the treatment of biological assets according to the recording of PTPN V and PSAK 69. That difference will have an impact on PTPN V's profits and losses. As seen in Table 1, there is a difference in the measurement and recording of 
the biological assets based on the implementation of the PSAK 69 at PTPN V. Because PTPN V includes all costs issued in relation to their biological assets as acquisition costs of the biological assets, such as costs of maintaining a nursery, land preparation, planting, fertilizers, and maintenance, including labor costs in relation to those activities, general cost allocation and administration as well as loan fees used to produce plants when the plants are immature, there must be a difference between the acquisition cost of the biological assets and the fair value of the assets. The implication is that PTPN V's profits and losses will be misinterpreted. The fair value can be measured from the active market (Starova, Cermakova, Hlavsa, Vostrovska, and Leva, 2016).

Based on the result of the survey on the fair value of the plantation plants, the information on the fair value of the plantation plants is around Rp70,000,000 to Rp150,000,000 per hectare. Meanwhile, the estimate of the cost at the point of sale issued by the company is the cost of buying and selling the plant which is notarized with an estimated fee of Rp6,000,000 per 2 hectares. The total area of mature trees that PTPN V owns is $\mathbf{5 8 . 7 4 2}$ hectares. Hence, it is common for the mature trees to amount around Rp4,111,940,000,000 to $\mathrm{Rp} 8,811,300,000,000$. The estimated total cost at the point of sale of the mature trees is Rp176,226,000,000. It can therefore be concluded that the fair value minus the cost at the point of sale is around Rp3,935,714,000,000 to Rp8,635,074,000,000.

If compared to the acquisition cost of the mature trees available in the financial position statement, which includes the fair value of the assets, there is a difference of $\mathrm{Rp} 1,464,347,117,147$ to $\mathrm{Rp} 6,163,707,117,147$. This difference is profit which has not yet been realized because the application of the fair value of the mature trees is higher than their acquisition cost and the profit must be recognized or admitted in the comprehensive income statement in 2016. The minimum profit recognized by PTPN V is approximately $\mathrm{Rp} 1,464,347,117,147$ and the maximum profit is approximately Rp6,163,707,117,147. Thus, it can be concluded that the profit gained by PTPN V in the 2016 period has been interpreted too low. With the increase in the fair value of the assets, the financial situation of the company has improved, which in turn can help facilitate the acquisition of foreign sources in terms of funding, and this situation may also provide assistance in obtaining grants and other financial aid (Bartunkova, $\mathrm{Ph}$, and Pavel, n.d.).

\section{Discussion}

Based on the above description, the following table provides a summary of the comparison of PTPN V's biological assets based on the PSAK 69:

Table 1. Difference in Treatment of Biological Assets Based on PTPN V and PSAK 69

\begin{tabular}{|c|c|c|c|}
\hline No & $\begin{array}{l}\text { Accounting } \\
\text { Treatment }\end{array}$ & Based on PSAK 69 & Based on PTPN V \\
\hline 1 & Recognition & Recognized as Mature and Immature & Recognized as Mature and Immature \\
\hline 2 & Measurement & $\begin{array}{l}\text { Using fair value } \\
\text { Measured in the initial recognition and } \\
\text { on the next reporting date based on fair } \\
\text { value minus estimated cost of sales } \\
\text { If in a period the biological assets } \\
\text { experience an increase or decrease in fair } \\
\text { value, this must be recognized as profit } \\
\text { or loss and recorded in the income } \\
\text { statement in the current year }\end{array}$ & $\begin{array}{l}\text { Using historical cost } \\
\text { Measured based on the accumulation of } \\
\text { previous value. Recorded value comes } \\
\text { from acquisition of mature assets cost } \\
\text { minus accumulation of amortization } \\
\text { In the income statement there is no profit } \\
\text { or loss from the biological assets }\end{array}$ \\
\hline 3 & Interpretation & Interpreted to fixed asset component and & Interpreted to fixed asset component and \\
\hline
\end{tabular}




\begin{tabular}{llll}
\hline No & $\begin{array}{l}\text { Accounting } \\
\text { Treatment }\end{array}$ & Based on PSAK 69 & Based on PTPN V \\
\hline & stock & stock \\
\hline 4 & Disclosure & $\begin{array}{l}\text { Company is advised to make details on } \\
\text { types and number of biological assets, biological assets, depreciation method, } \\
\text { depreciation method, age benefits, and age benefits, and depreciation tariffs } \\
\text { depreciation tariff also the reconciliation } \\
\text { of the carrying amount in the beginning } \\
\text { and the end of the period }\end{array}$ \\
\hline 5 & Recording & Based on fair value & Based on acquisition cost \\
\hline
\end{tabular}

Sources: (Ikatan Akuntan Indonesia, 2017; PT Perkebunan Nusantara V, 2016)

According to Table 1, there are several applications of the accounting treatment of the biological assets of PTPN V which do not comply to the PSAK 69 (IAS 41). They are fund in the components of measurement and transaction recording of the biological assets. Similar research by Mates, Grosu, Hlaciuc (2015) also concludes that there is a significant difference between the implementation of the IAS 41 and the treatment of the biological assets applied by agricultural companies in Rumania, as the IAS 41 is considered difficult to apply in agricultural companies.

As for the measurement of the biological assets, PTPN V measured the assets based on the historical cost and their measurement was based on the accumulation of the previous value of the biological assets. PTPN V must have measured them based on the fair value reduced by estimate of cost to sell and recognize profit or loss gained from the assets in their income statement in the current period. This is relevant because agriculture is a specific asset and the production period takes several decades and causes the value of the reported assets to be distorted. Therefore, inaccurate information on the total value of assets may be provided in financial statements (Starova et al., 2016). However, agriculture companies generally encounter difficulties when estimating a reliable fair value, particularly when there is no active market (Malis, Sacer, and Brozovic, 2016). In addition, as PTPN V uses the historical cost method, they do not recognize the profit and loss of the biological assets in the income statement. The implication of this is that the income statement and the statement of financial position of PTPN V are misinterpreted, which has an effect on the decisions made by those using the information. Based on the results of this research, the income statement of PTPN V was misinterpreted (interpreted too low) from Rp1,464,347,117,147 to Rp6,163,707,117,147.

In addition to recognition and measurement, there is also an inconsistency in the recording of the transactions of the biological assets of PTPN V in accordance to the PSAK 69 (IAS 41). PTPN V records its biological assets based on the acquisition costs or historical costs, however the PSAK 69 requires the assets to be recorded based on their fair value. The use of the fair value concept is more accurate for biological assets since their biological transformation will eventually cause the value of the assets or trees to increase. Hence, the application of the fair value makes the interpreted information relevant to all decision makers. This is consistent with the stakeholder theory.

\section{Conclusions}

Based on the explanation provided above, it can be concluded that PTPN V has not yet implemented the PSAK 69 (IAS 41) as several components of their financial statements do not comply with the PSAK. Those components are related to the recognition, measurement, and recording of the biological assets. Meanwhile, the interpretation and revelation of the biological assets are in accordance with the PSAK 69. In addition, as 
there is a difference in the measurement and interpretation of the biological assets, there is a misinterpretation or misstatement in the profits of PTPN V, as the company's profits are understated.

\section{References}

Anggraeningtyas Elvi Mutiara Dara, T. (2013). Implementation of International Accounting Standards (Ias) 41 About Biological Assets on Pt. Plantation Nusantara Ix (Persero) Getas Gardens (Doctoral dissertation, Faculty of Economics). Bartunkova, I. L., Ph, D., \& Pavel, I. (n.d.). Use of fair value in agriculture, (2006).

Burnside, A. (2005). IAS 41 and The Forest Industry: A Study of the Forest Products Companies Perception of the IAS 41 Today. Goteborg University.

Donaldson, T., \& Preston, L. E. (1995). The Stakeholder Theory of the Corporation: Concepts, Evidence, and Implications. The Academy of Management Review, 20(1), 65-91.

IASC. (2001). International Accounting Standard IAS 41: Agriculture. London.

Ikatan Akuntan Indonesia. (2017). Pernyataan Standar Akuntansi Keuangan.

International Accounting Standards Board (IASB). (n.d.). Agriculture.

Jensen, M. C. (2001). Value Maximization, Stakeholder Theory, and the Corporate Objective Function.

Malis, S. S., Sacer, I. M., \& Brozovic, M. (2016). Valuation of Biological Assets Under Ias 41 - the Case of Listed and Large Companies in Croatia, (December), 44-50.

Mates, D., Grosu, V., Hlaciuc, E., Bostan, I., Bunget, O., Domil, A., ... \& Artene, A. (2015). Biological assets and the agricultural products in the context of the implementation of the IAS 41: A case study of the Romanian agro-food system. Archives of Biological Sciences, 67(2), 705-714.

PT Perkebunan Nusantara V. (2016). Annual Report. Indonesia: PT Perkebunan Nusantara V (Persero).

Stárová, M., Čermáková, H., Hlavsa, T., Vostrovská, H., \& Levá, M. (2016). Evaluation of applicability of IAS 41Agriculture to the valuation of growing forest stands and their accounting treatment in the Czech Republic. Journal of Forest Science, 62(9), 429-440. 